\title{
¿HACERNOS LOS SUECOS? LA PROSTITUCIÓN Y LOS LÍMITES DEL ESTADO*
}

\author{
Pablo de Lora \\ Universidad Autónoma de Madrid
}

RESUMEN. El ejercicio de la prostitución en España es una actividad de dudosa calificación jurídica. Si bien no constituye un delito, la prostitución no se encuentra legalmente amparada pues se estima que el contrato mediante el cual se intercambia sexo por dinero es nulo por ser la causa contraria a la moral. Ello provoca que la relación entre la prostituta y los intermediarios de su actividad (comportamiento éste que sí es delictivo) no pueda quedar amparada por el Derecho laboral. Dicho marco jurídico es, con matices, el del reglamentarismo, uno de los modelos normativos que, junto con el prohibicionismo y el abolicionismo, han disciplinado históricamente la actividad de las prostitutas. El prohibicionismo y el abolicionismo son las manifestaciones de un Estado perfeccionista que no se toma en serio el valor de la autonomía personal de aquellas mujeres que, consciente y competentemente, desean recibir una contraprestación por sus servicios sexuales, de la misma manera que otros muchos individuos venden su fuerza de trabajo empleándose en oficios que también pueden estimarse penosos o indignos. En este trabajo se defiende, frente a los anteriores modelos, una forma de «reglamentarismo reforzado" que propugna, en esencia, la laboralización de la prostitución - con los matices propios del ejercicio de una actividad que es en todo caso «especial»- en aras a la mejor protección de los intereses de las mujeres prostitutas.

Palabras clave: reglamentación de la prostitución, abolición de la prostitución.

ABSTRACT. Although not a crime, prostitution in Spain is not a legally protected activity. According to the Spanish Civil Law, the contractual relation between the prostitute and the client is null and void because of its immorality. Therefore, it is also inconceivable as a job under our current Labour law. This legal framework is known as «reglamentarismo» as opposed to «abolicionismo" and "prohibicionismo", both of which are the proper outcome of a perfectionist State which does not take women's personal autonomy seriously. In this paper I defend that not all prostitution is «forced prostitution" and that we should not foreclose the possibility of there being women who freely sell their sexual services. In such cases I defend a «new» form of "reglamentarismo", which, in essence, advocates for the widening of the extent and scope of the Spanish worker's legal rights to cover the prostitute's activity in order to better protect his or her interests.

Keywords: regulation of prostitution, abolition of prostitution.

\footnotetext{
* Este trabajo forma parte del proyecto de investigación SEJ 2005-08885/JURI. Quisiera agradecer a Águeda Quiroga, Elena Beltrán, Aurelio Desdentado, Eva Desdentado, Ana De la Puebla y Liborio Hierro los valiosos comentarios que me formularon tras la lectura de una versión inicial de este texto.
} 
Se dice que la esclavitud ha desaparecido de la civilización europea, y es un error. Existe todavía; sólo que no pesa ya sino sobre la mujer, y se llama prostitución ${ }^{1}$.

\section{INTRODUCCIÓN}

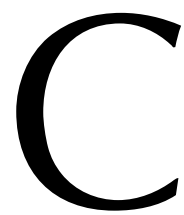

elebraba Amelia ValCárcel en las páginas de El País que la Comisión Mixta de Derechos de la Mujer del Congreso y del Senado haya concluido que la prostitución no es un modo de vida deseable y aceptable ${ }^{2}$. La verdad es, sin embargo, que el Parlamento ha perdido una oportunidad de oro para lograr una mejor protección de las mujeres que se dedican a la prostitución, incluso si hubiese acertado en su juicio sobre la incorrección moral de intercambiar sexo por dinero ${ }^{3}$. Ambas cosas - regular mediante un elenco de permisos, obligaciones y prohibiciones una actividad que, en el fondo, se repudia— no son incompatibles, aunque en una lectura apresurada lo parezcan.

La prostitución en España no constituye un comportamiento delictivo. Sí son delitos, en cambio, las conductas consistentes en forzar a alguien a prostituirse, o en lucrarse de la prostitución ajena ${ }^{4}$. Que la prostituta no sea una delincuente no quiere decir, empero, que su actividad esté bendecida por el ordenamiento jurídico. Ocurre más bien lo contrario si nos atenemos a los pronunciamientos de los órganos jurisdiccionales encargados de interpretar y aplicar el Derecho.

En general, tanto ahora como antaño, la prostitución ha sido considerada una actividad inmoral o ilícita, lo cual ha permitido, por poner dos, entre otros ejemplos posibles, que un casero pueda resolver el contrato de arrendamiento en aplicación de las entonces vigentes leyes de arrendamientos urbanos y de propiedad horizontal ${ }^{5}$ o que la prostitución de la hija o nieta pudiera ser justa causa de desheredación ${ }^{6}$. Pero en lo que a mí más me interesa, el ejercicio de la prostitución no resulta amparado por el Derecho laboral. La razón se halla, como han señalado repetidamente los tribunales invocando el artículo 1.275 del Código Civil, en que estamos ante un contrato con objeto

${ }^{1}$ Hugo, V., Los miserables (Primera parte, Libro V, Capítulo VIII).

2 «¿La prostitución es un modo de vida deseable?», El País, 21 de mayo de 2007, p. 15.

3 Como definición de la prostitución, ésta es una formulación que tiene que sortear la objeción de que también el matrimonio, en algunos supuestos, es un modo de trocar sexo por dinero como defendieron Friedrich ENGELS y Simone DE BEAUVOIR. Lo que diferencia a la mujer de clase burguesa casada por el rito católico o protestante de la cortesana, señala ENGELS, es que la primera «... no alquila su cuerpo a ratos, como una asalariada, sino que lo vende de una vez para siempre, como una esclava» (1982, p. 90); véase en la misma línea, aunque desde presupuestos bien distintos, EDLund, L., y KoRn, E., 2002, p. 183.

${ }_{4}$ Véase el artículo 188.1 del Código Penal. La prostitución forzada existe, de acuerdo con este artículo, cuando hay violencia, intimidación, engaño o aprovechamiento de la situación de vulnerabilidad o necesidad ajena. Por otro lado, el proxenetismo fue reintroducido como delito en el año 2003 después de haber sido despenalizado en 1995 (véase, infra nota 35).

5 A ese respecto véanse, entre otras, las sentencias del Tribunal Supremo de 22 de mayo de 1993 (RJ 1993/3724, FJ 1. ${ }^{\circ}$ ) o de la Audiencia Provincial de la Coruña de 13 de octubre de 1993 (AC 1993/2166, FJ 3..$^{\circ}$. En la más reciente sentencia de la Audiencia Provincial de Guipúzcoa de 19 de octubre de 2000 se considera el ejercicio de la prostitución como una actividad «ilícita» (JUR 2001/44291, FJ 4. ${ }^{\circ}$ ). octubre.

${ }^{6}$ Así lo establecía el artículo 853.3 del Código Civil hasta la reforma operada por Ley 11/1990 de 15 de 
y/o causa ilícita (por opuesta a la moral) ${ }^{7}$. Esta falta de cobertura legal tiene consecuencias indeseables para las prostitutas: desde las más inmediatas, como no poder reclamar judicialmente el pago por un servicio prestado (de ahí la figura del «chulo») ${ }^{8}$, o disfrutar de las condiciones laborales mínimas de las que goza cualquier otro trabajador (vacaciones, jornada, etc.), hasta la imposibilidad de ser beneficiaria de cualquiera de las prestaciones asistenciales que el Estado vincula a la existencia de una relación laboral. Por poner un botón de muestra extraído de la jurisprudencia, una mujer que fallece en accidente de tráfico cuando regresaba a su domicilio desde el club en el que se prostituía, en la furgoneta que el dueño ponía a disposición de las mujeres, no es víctima de un accidente laboral y por tanto sus dos hijos no reciben la indemnización que en otro caso sí les correspondería de acuerdo con el artículo 115.2 del Real Decreto 1/1994 de 20 de junio de Seguridad Social ${ }^{9}$.

A veces, sin embargo, y tal vez como forma de salvar algunos muebles, los jueces han accedido a considerar que el dueño de un local de alterne puede ser condenado por el delito consistente en imponer a las mujeres que allí alternan condiciones laborales que perjudiquen sus derechos legales o los derivados del Convenio colectivo, aunque, formalmente, ni aquél sea empleador, ni las mujeres que en su local ejercen la prostitución sean sus empleadas ${ }^{10}$. La razón es que: «De lo contrario el más desprotegido debería cargar también con las consecuencias de su desprotección» ${ }^{11}$.

Y ya que hablamos de alterne, es pertinente destacar que esta actividad sí recibe una cierta sanción jurisdiccional, a pesar de, por un lado, su posible encuadramiento en el género de las actividades inmorales (no parece que incitar al consumo de alcohol

${ }^{7}$ Entre las más contundentes expresiones de tal doctrina, la del Juzgado de lo Social de Vigo de 7 de mayo de 2004 (AS 2004/1276): «La prostitución es una violación continua y reiterada de la dignidad de la mujer; es un ataque frontal contra su arcano más íntimo, esto es, su capacidad de decidir en plena libertad sobre su indemnidad e intimidad sexual. Desde otra perspectiva, la prostitución igualmente es una manifestación y proyección concreta de la violencia de género, porque estrangula desde el comienzo la posibilidad de desarrollar con dignidad la personalidad de la mujer... Con estos dos axiomas ya podemos inferir que el ejercicio de la prostitución no puede ser objeto lícito de un contrato de trabajo, porque su objeto, el fin explotado para el beneficio patronal, es la negación de la libertad sexual como expresión de destrucción de la capacidad de decidir por sí misma una persona cuándo, con quién y de qué forma permite y quiere donarse con y en otra para lograr enriquecer su propia personalidad» (FJ 2. ${ }^{\circ}$. En el mismo sentido véase el voto particular que formulan tres magistrados a la Sentencia del Tribunal Superior de Justicia de Andalucía de 4 de diciembre de 2003 (AS 2003/3638).

${ }^{8}$ Normalmente, cuando un contrato es nulo las partes se restituyen lo que se hayan transmitido en virtud del acuerdo. Sin embargo, cuando la nulidad deriva de que la causa o el objeto del contrato son ilícitos, las partes carecen de reclamación entre sí.

9 Véase la sentencia del Tribunal Superior de Justicia de las Islas Baleares de 9 de enero de 1992 (AS 1992/201, FJ 3. ${ }^{\circ}$ ). El colmo de la insensibilidad o desprotección es la Sentencia del Tribunal Central de Trabajo de 30 de mayo de 1962 que declara igualmente nulo el contrato de trabajo que mantenían las limpiadoras de un meublé con los regentes del mismo pues se entiende que la ilicitud de la causa se proyecta también a esa relación laboral. En los propios términos del magistrado: «... conocidas por aquellas —las limpiadoras — las actividades desarrolladas en éste —el establecimiento— su colaboración consciente proyecta la ilicitud de la causa sobre la relación entre las partes litigantes ya que no es posible desconocer la existencia entre el móvil del contrato y su finalidad inmoral, a la que, con plenitud de conocimientos, coadyuvaban las accionantes...» (la cita procede del artículo de Diego DE LA VILLA DE LA SERNA, 2004, p. 5). El efecto para las limpiadoras es que no se reconocen los salarios por el trabajo prestado.

${ }^{10}$ La razón es sencillamente, que el contrato laboral no «existe» por ser nulo radicalmente dadas las causas ya comentadas (ser el objeto o la causa ilícitos).

${ }^{11}$ Sentencia del Tribunal Supremo de 12 de abril de 1991 (RJ 1991/2704, FJ 6. ${ }^{\circ}$. La doctrina de esta sentencia ha sido recientemente reiterada por el propio Tribunal Supremo en su Auto 1922/2005 de 5 de octubre (JUR 2005/235566, FJ 2. ${ }^{\circ}$. 
mediante la simulación de una suerte de flirteo sea precisamente una instancia del despliegue de la virtud), y de que, de otra parte, es vox populi que las empleadas en estos locales no se limitan a la incitación o al cortejo sino que finalmente venden «servicios sexuales» haciendo uso de las habitaciones que en ese mismo club se ponen a su disposición para ser alquiladas por horas ${ }^{12}$. Sea como fuere, el alterne, se ha dicho recientemente por parte de la Audiencia Nacional y el Tribunal Supremo, sí puede configurarse como una relación laboral por cuenta ajena ${ }^{13}$. Bien es cierto que otra sala del Tribunal Supremo ha considerado que la regencia de un local de alterne no es representativa de la buena conducta cívica que la legislación civil exige para obtener la nacionalidad española de acuerdo con el artículo 22.4. del Código Civil ${ }^{14}$.

Todo lo anterior es, en todo caso, una muestra suficientemente elocuente de lo pantanoso del terreno que pisamos cuando tratamos de saber qué calificación jurídica recibe la prostitución en España. No es difícil sospechar que esa relativa incertidumbre es el producto del fariseísmo social imperante sobre una actividad abrumadora tanto en lo que se refiere a sus cifras de negocio cuanto en lo que hace al número de personas que se sitúan en el lado de la oferta y la demanda ${ }^{15}$. A pesar de lo que ambos datos muestran, socialmente la prostitución sigue sin ser «admisible». El sistema jurídico, por tanto, no puede presentarla como una ocupación o servicio más, aunque tampoco su criminalización resulta ser el precipitado jurídico inmediato de nuestra (des)consideración moral sobre la misma ${ }^{16}$.

${ }^{12}$ En esta misma línea de denuncia de la contradicción se pronuncia REY et al., 2004, pp. 198-199 comentando aquellas sentencias de la jurisdicción social en las que se distingue, en relación a la misma persona, entre períodos de jornada laboral dedicados al alterne (que sí pueden recibir la consideración de actividad laboral) de aquellos otros en los que la dedicación es a la prostitución (que no pueden recibir aquella consideración). Para REY estamos ante un caso de «esquizofrenia jurídica» ya que se debería entender que toda la relación está viciada.

${ }^{13}$ Sentencia de la Audiencia Nacional de 23 de diciembre de 2003 (AS 2003/3692, FJ 6. ${ }^{\circ}$ ), luego confirmada por la Sentencia del Tribunal Supremo de 27 de noviembre de 2004 (RJ 2004/8063, FJ 5. ${ }^{\circ}$ ). En este asunto se dilucidaba la posible inscripción de la Asociación de Empresarios de locales de alterne «Mesalina» en el Registro de Asociaciones Empresariales dependiente del Ministerio de Trabajo en virtud de lo dispuesto en la Ley 19/1977 de 1 de abril. En otra constelación de asuntos relativos a la aplicación de la ley de extranjería, se insiste en la misma idea: el alterne no constituye un «medio ilícito de vida» que justifique la expulsión del país del extranjero según lo que preveía el artículo 26.1.f) de la entonces vigente Ley Orgánica 7/1985 de 1 de julio de Derechos y Libertades de los Extranjeros en España; véanse en ese sentido las sentencias del Tribunal Supremo de 21 de julio de 1995 (RJ 1995/5948, FJ 3.'), de 12 de noviembre de 1999 (RJ 1999/10004, FJ 3..$^{\circ}$ ) y de 7 de abril de 2003 (RJ 2003/3420, FJ 3..$^{\circ}$.

${ }^{14}$ STS de 12 de noviembre de 2002 (RJ 2003/955, FJ 4. ${ }^{\circ}$ ). Esta decisión contó con la disidencia de dos magistrados que consideraban en su voto particular que: «... descalificar la conducta de una ciudadana, que cumple sus deberes familiares, sociales, fiscales y laborales, porque sea titular de un local, en el que mujeres alternan con clientes y donde el propio Tribunal de instancia reconoce que no se desarrollan actividades ilícitas, no se ajusta a la realidad social y jurídica de nuestro tiempo, como lo evidencia la Sentencia del Tribunal de Justicia de las Comunidades Europeas de 20 de noviembre de 2001 o la promulgación por la Generalidad de Cataluña del Decreto 217/2002, de 1 de agosto» (FJ 6. ${ }^{\circ}$. Sobre dicha sentencia se hablará más adelante.

${ }^{15}$ Las magnitudes bailan al son de las fuentes que uno consulte. Por poner sólo un par de ellas sobre el tapete, de acuerdo con GUEREÑA, la prostitución mueve en España en torno a 18.000 millones de euros anuales y, según FERnÁndez FERnÁndeZ, R., et al., 12.000 millones de euros anuales (véase 2007, p. 9). Según los datos del Informe de la Comisión Mixta, el 6\% de la población española es consumidora habitual de prostitución (p. 22).

${ }^{16}$ Como de «hipócrita huida del problema» califica también QuINTERO OlIVARES el actual tratamiento jurídico-penal de la prostitución en España; véase 2006, p. 184. 


\section{PROHIBICIONISMO, REGLAMENTARISMO Y ABOLICIONISMO}

En un intento de sembrar un poco de orden, los estudiosos han identificado tres grandes modelos normativos que han disciplinado y disciplinan la prostitución: prohibicionismo, reglamentarismo, y abolicionismo ${ }^{17}$. En el primer caso, los comportamientos de las dos partes (cliente y prostituta) son penalmente castigados (como ocurre en todos los Estados de los Estados Unidos salvo Nevada) o bien sólo el del cliente, como sucede en Suecia desde $1999^{18}$, o bien sólo el de la prostituta como es el caso de Egipto ${ }^{19}$.

El reglamentarismo se caracteriza por concebir la prostitución como un mal menor tal y como rotundamente se expresaba el célebre médico Federico Rubio y Gali, uno de sus valedores de antaño: «Sólo un espíritu hipócrita puede dejar de confesar que la casa de lenocinio mengua los vicios solitarios, la prostitución clandestina, la seducción doméstica y la asquerosa inversión sexual. Paréceme, pues, que bien puede perdonarse el bollo por el coscorrón ${ }^{20}$. El reglamentarismo habría sido la moneda corriente en España desde la Edad Media y hasta que Felipe IV promulga las Pragmáticas de 1623 y 1661 (en lo que Jean Louis GUEREÑA considera la «Edad de Oro» del reglamentarismo) ${ }^{21}$ y desde 1845 -momento en el que el Gobernador de Zaragoza establece las primeras disposiciones para la «policía médica de las mujeres públicas»— hasta 1956 (salvada la excepción del período 1935-1941) ${ }^{22}$. En esa «Edad de Plata» que conforman la segunda mitad del siglo XIX y la primera mitad del XX, la reglamentación de la actividad tiene como misión central la de la prevención de las enfermedades de transmisión sexual. Como a finales del XIX señalaba con crudeza Romualdo Fernández Fragoso, pediatra sevillano y padre de la micología española: «Ya que la prostitución es a la sociedad como las alcantarillas y letrinas a una gran ciudad, esforcémonos en evitar en lo posible la infección moral y física con una buena reglamentación, de igual modo que procuramos resguardar nuestros organismos de los gases mefíticos construyendo buenos sistemas de alcantarillado» ${ }^{23}$.

La reglamentación ha llevado aparejada el estigma social y jurídico de la prostituta. Repare el lector en que, a juicio de Fernández Fragoso, de lo que se trata es de evitar la infección física y «moral». A ese fin se encaminan una batería de castigos o previsiones reglamentarias tan dispares, pero en todo caso tan gravosos, como compartir censo con otras poblaciones marginales (verbigracia, los vagabundos, dementes, ciegos, idiotas o sordomudos) ${ }^{24}$, o, ya en pleno reglamentarismo franquista, no poder estar ins-

${ }_{17}$ Ésta es una tripartición de la que ya se hacía eco Luis JIMÉNEZ DE AsÚA en 1928 (p. 26).

${ }^{18}$ Es la conocida como Sexköpslag o «ley de compra de sexo», que establece un castigo de multa o prisión de hasta 6 meses a quien requiera cualquier forma de servicio sexual a cambio del pago en dinero o especie, independientemente del lugar donde se realice. Se castiga igualmente la tentativa y las distintas formas de autoría y participación penal. La ley cuenta, según distintos estudios, con un porcentaje de apoyo por parte de la población que oscila entre el 50 y el 70\% (HEIM y MONFORT, 2005, p. 784). Una muy exhaustiva presentación de sus antecedentes es la de HEIM y MONFORT, 2005, pp. 776-784.

${ }^{19}$ Lousada Arochena, J. F., 2005.

${ }^{20}$ GuEREÑA, op. cit., p. 188. El topos clásico del argumento es el tratado De Ordine (II.IV, 2) de Agustín DE HIPONA donde se afirma: «Cerrad los prostíbulos y la lujuria lo invadirá todo».

${ }^{21}$ Ibid., p. 13.

${ }^{22}$ Otros autores, sin embargo, consideran que el reglamentarismo, propiamente entendido, aparece en Francia en 1802, extendiéndose por toda Europa por mor de las guerras napoleónicas; véase así, HEIM, D., y MONFORT, N., 2005: 772.

${ }^{23}$ La prostitución en las grandes ciudades (Estudios de bigiene social), Madrid: Librería de la Fe, 1887, p. 11 (citado por GUEREÑA, 2003: 24).

${ }^{24}$ Tal era el caso del censo de Jerez de la Frontera de mediados del XIX (GUEREÑA, 2003: 163). 
critas las prostitutas en las listas electorales del tercio familiar ${ }^{25}$. Que la prostituta era considerada un peligro público del que precaverse lo demuestra el hecho de que en el Reglamento para la vigilancia y servicio sanitario de las prostitutas promulgado por el gobernador civil de Barcelona Romualdo Méndez de San Julián en 1867 se disponían medidas para proteger al hombre casado, viudo, con hijos o hijo de familia, de la tentación de enamorarse de una prostituta prohibiendo sacarla del padrón especial para que vivieran amancebados ${ }^{26}$. Y es que en esos Registros de «mujeres públicas» que fueron característicos del reglamentarismo, era muy fácil entrar pero muy complicado salir. Tan sencillo era lo primero que, de acuerdo con las disposiciones del Reglamento madrileño de 1847, la inscripción podía ser practicada de oficio por el comisario, incluso contra la voluntad de su interesada: bastaba con que aquél considerara «notoria» dicha dedicación. A partir de ese momento la prostituta se convertía en una mujer pública en sentido literal: perdía sus señas de identidad propias pasando a tener un nombre de «profesional» y era despojada de todo derecho a la intimidad. En otros momentos, la mujer que se prostituía, y sólo ella, podía ser acusada de contagio sifilítico ${ }^{27}$. A todo ello añádasele que esa inscripción tampoco era «gratis». Lejos de ser una forma de «asistencia sanitaria» para la mujer prostituta, su censo era lo que permitía la exacción correspondiente con la que mantener los servicios públicos de vigilancia e higiene. Tal jugosa fuente de financiación explica la disputa que durante algunos períodos mantuvieron los municipios con los gobiernos civiles por hacerse con la gestión de ese negociado. El Estado reglamentarista era también el Estado «proxeneta» ${ }^{28}$.

El abolicionismo tiene unas coordenadas históricas más precisas: el manifiesto de Josephine Butler de $1870^{29}$ en contra de las Contagious Disease Acts y que fue el germen de la creación en 1875 de la Federación británica, continental y general contra la prostitución reglamentada por los Estados ${ }^{30}$. La plasmación normativa del abolicionismo tiene un primer hito con el Convenio internacional relativo a la represión de la Trata de Blancas de París (4 de mayo de 1910), que propugna en su artículo 1 el castigo para todo aquel que reclute, induzca o desencamine a alguien para satisfacer pasiones ajenas aun con su consentimiento ${ }^{31}$. Con el mismo espiritu se fraguó posteriormente el gran instrumento jurídico abolicionista: el Convenio para la represión de la trata de personas y de la explotación de la prostitución ajena (también designado como Tratado de Lake Success) adoptado por la Asamblea General de Naciones Unidas el 2 de diciembre de 1949, y cuya entrada en vigor se produjo el 25 de julio de $1951^{32}$. Así, en su artículo 1 se establece el compromiso de las partes de «castigar a toda persona que, para satisfacer las pasiones de otra: 1) concertare la prostitución de otra persona, aun con el con-

${ }^{25}$ Ibid., p. 422.

${ }^{26} I d$., p. 182. En general, a la prostituta se le prohíbe vivir en compañía de hombre (aunque sea el padre, marido o hijo, $i d$., p. 126).

27 GUEREÑA, 2003: 124-125.

${ }^{28}$ Ibid., pp. 127, 209.

29 «An Appeal to My Countrymen».

${ }^{30}$ La sección española de la Federación abolicionista se crea en 1882. Los primeros veinticinco inscritos fueron todo hombres y entre ellos se encuentran institucionistas célebres como Giner de los Ríos o Gumersindo de Azcárate, así como a Emilio Castelar, Pi y Margall; GuEREÑA, 2003: 358. También JimÉNEZ DE AsúA se declaró públicamente un entusiasta abolicionista (véase Libertad de amar..., op. cit., p. 27).

31 Su ratificación por parte de España provoca la modificación del Código Penal de 1870 y ejerce una gran influencia en el de 1928; véase en ese sentido GUEREÑA, 2003: 241.

${ }^{32}$ La adhesión de España se produjo en 1962. 
sentimiento de tal persona; 2 ) explotare la prostitución de otra persona, aun con el consentimiento de tal persona». En España, y en cumplimiento de esa obligación, el Código Penal fue reformado en 1963 para castigar las conductas «participativas» (el denominado «rufianismo» y «proxenetismo locativo») en la prostitución ajena, si bien, el abolicionismo ya había hecho su aparición en escena con las Pragmáticas de Felipe IV a las que antes se ha aludido, y en los períodos que van de 1935 a $1941^{33}$ y a partir de 1956 con la promulgación del Decreto de 3 de marzo en el que se ordena el cierre de las mancebías ${ }^{34}$. Con posterioridad, merece ser destacado el Convenio n. ${ }^{\circ} 197$ del Consejo de Europa sobre la lucha contra la trata de seres humanos hecho en Varsovia en 2005 y la Resolución del Parlamento Europeo de 2 de febrero de 2006 en la que se insta a los Estados miembros a que «... luchen contra la idea de que la prostitución es equiparable a la realización de un trabajo» ${ }^{35}$.

\section{3. ¿EN QUÉ CONSISTE EL ABOLICIONISMO?}

No resulta fácil definir el abolicionismo, salvo como pars destruens del reglamentarismo: el Estado no debe dar pábulo, mediante la regulación, a una actividad básicamente degradante e indigna; antes bien, debe dirigir sus esfuerzos en pos de su desaparición. Mientras tanto, a la prostituta no se le puede añadir la carga de la sanción penal o administrativa por su dedicación (que es lo característico del prohibicionismo) con lo que su oficio es a fin de cuentas «tolerado». Esta es la situación que, con matices, vivimos en España desde 1956, junto con países tales como Bélgica, Reino Unido, Francia e Italia ${ }^{36}$.

Tiene razón Amelia VALCÁRCEL, y los abolicionistas, cuando señalan que del hecho de que la prostitución exista no se sigue que tenga que seguir existiendo. Las razones de índole pragmática aconsejan que el Estado «ordene» una actividad cuando la misma es tolerable. También ha existido la esclavitud y no por ello la humanidad ha cedido en su empeño por desterrarla, nos repiten machaconamente los voceros del abolicionismo. ¿Es esto último lo que pretendemos en España o en tantos otros países donde las prostitutas siguen desamparadas por el ordenamiento aunque no castigadas? Si la

33 Años durante los que cabe entender que estuvo en vigor el Decreto 1935 promulgado por el ministro de Trabajo Federico Salmón Amorío y en cuyo artículo 1 se declaraba que el ejercicio de la prostitución no se reconoce como medio lícito de vida.

${ }^{34}$ LOUSADA AROCHENA ha destacado que España nunca cumplió fielmente las obligaciones que derivaban del Tratado de Lake Success pues técnicamente hablando las prostitutas no pasaron a considerarse criminales, aunque si caían bajo la cobertura de la Ley de peligrosidad y rehabilitación social, pudiéndoseles imponer medidas de seguridad (véase LousADA AROCHENA, 2005). En realidad, del mencionado Tratado no se derivaba la necesaria consideración de la prostituta como delincuente (aunque sí de los terceros). La referencia clásica de la (encendida) defensa del Decreto de 1956 es la monografía de JiMÉNEZ ASENJO, magistrado del Tribunal Supremo y que fue miembro del Patronato de Protección de la mujer, Abolicionismo y prostitución, Madrid: Reus, 1963.

${ }_{35}$ Punto 3.i de la Resolución (Referencia INI/2004/2220, disponible en http://www.europarl.europa.eu). El Informe de la Comisión Mixta hace suya esta recomendación (véase p. 23).

${ }^{36}$ FERNÁNDEZ et al., 2007: 12 y QUINTERO OLIVARES, 2007: 190. Cabe señalar que, con la despenalización del proxenetismo que se produjo con la reforma del Código Penal de 1995, España también se alejó del cumplimiento del Tratado de Lake Success, aunque dicha reforma (corregida posteriormente en el año 2003) encontró el aplauso de destacados penalistas (véase por todos, MAQUEDA AbreU, M. ${ }^{a}$ L., «Feminismo y prostitución», El País, 1 de abril de 2006, p. 15). 
respuesta fuera afirmativa, esto es, si la analogía prostitución-esclavitud fuera certera, haríamos de la prostitución no ya una actividad «desregulada», como parece recomendar el abolicionismo, sino una conducta prohibida bajo la amenaza de la sanción penal para quien la fomenta o consume como ocurre en Suecia (y bajo el presupuesto de que la prostituta es sólo una víctima y nunca sujeto activo de delito alguno). De hecho, como antes señalaba, esto es lo que se hace en España y en otros muchos países ante las formas «no consentidas» de explotación sexual. En estos supuestos nadie discute que estamos no solo ante un modo de vida no deseable, sino ante un haz de conductas por parte del explotador que merecen la intervención punitiva del Estado. Pero lo cierto es que ni los propios miembros de la Comisión Mixta del Congreso y del Senado se creen que toda prostitución sea una forma de esclavitud, de explotación intolerable y denigrante, atentatoria contra los derechos más básicos, etc. Lo digo por lo siguiente.

En la p. 4 del Diario de la Marina, en su edición de 3 de febrero de 1846, se publicaba el siguiente anuncio: «Una negra se vende, recién parida, con abundante leche, escelente lavandera y planchadora con principios de cocina, jóven, sana y sin tachas, y muy humilde: darán razón en la calle O'Reilly, n. ${ }^{\circ} 16$, el portero». Este periódico se publicaba en la Cuba española cuando España aún no había abolido la esclavitud ${ }^{37}$. Imagino que sería imposible insertar este anuncio en los actuales medios de comunicación españoles. Éstos, sin embargo, publican todos los días un buen número de páginas en los que, de manera más o menos eufemística, con mayor o menor crudeza, se anuncian burdeles o mujeres - $\mathrm{y}$ hombres - que ofrecen sus servicios sexuales a cambio de un precio $^{38}$. Frente a este fenómeno (un negocio publicitario formidable) la Comisión Mixta recomienda al gobierno: «Solicitar a los medios de comunicación que en el marco de sus códigos deontológicos se planteen la renuncia a la publicidad relacionada con el comercio sexual para impedir el negocio de las organizaciones mafiosas dedicadas al comercio sexual» ${ }^{39}$. ¿Se imagina el lector lo que diríamos de un Parlamento que se mostrara así de timorato frente a quienes ganan dinero publicando anuncios de individuos que se venden —ahora sí, literalmente- como esclavos o de quienes mercadean con ellos?

El espacio, por tanto, de la prostitución voluntaria no parece ser un espacio vacío. Ni por razones conceptuales, ni por las implicaciones normativas que acabamos de indicar. A veces, empero, pareciera que sí lo es, que no cabe hablar de mujeres que libremente - todo lo libremente que otras y otros muchos han decidido dedicarse profesionalmente a lo que se dedican - ejercen la prostitución: «La afirmación de que la prostitución no es más que un ejemplo de contrato entre individuos iguales en el mercado — señala Carole PATEMAN — es otra ilustración de la presentación de la sumisión como libertad $\gg^{40}$. Es más, negar que sea concebible que la mujer que se prostituye pueda hacerlo voluntariamente es la estrategia frecuente empleada por quienes propugnan bien el prohibicionismo, bien el mantenimiento del actual status quo normativo (de rai-

${ }^{37}$ Lo hizo, paulatinamente, a partir de 1870. En 1880 fue completamente abolida en la península y en los territorios de ultramar. El anuncio lo he obtenido del estudio de GÓMEZ MARTínEZ, J. L.: http://www.ensavistas.org/antologia/XIXE/castelar/esclavitud /anuncios.htm.

${ }^{38}$ En la edición de El País que hojeo cuando escribo estas líneas (5 de julio de 2007), son 3 las páginas de «Relax». Según datos del propio Informe (p. 23), dicho periódico publica 702 anuncios de este tipo en un día laborable, ingresando por ello en torno a los cinco millones de euros anuales.

${ }^{39}$ Véase la p. 25 del Informe.

40 1983: 564 . 
gambre abolicionista) como hace VALCÁRCEL. Así, en la p. 20 del Informe de la Comisión Mixta de Derechos de la Mujer del Congreso y del Senado se puede leer que «... a los efectos de la intervención del Estado nada aporta la distinción entre prostitución libre o forzada que olvida que el ejercicio de la prostitución atenta contra la dignidad de las personas que la ejercen ${ }^{41}$. Parafraseando a Amelia VALCÁRCEL, cabe señalar que a nadie de las que bendicen y aplauden este Informe o, alternativamente, censuran el intento del gobierno catalán de regularizar la prostitución en Cataluña o la solución adoptada en los Países Bajos y Alemania (véase infra), le gusta hablar de ese tipo de prostitución ${ }^{42}$. Bajo fórmulas tales como «no estamos ante el auténtico problema que hay que resolver» se elude esa misma cruda realidad a la que VALCÁRCEL apela en su artículo ${ }^{43}$ : la existencia de mujeres que perfectamente informadas y capaces quieren seguir ejerciendo su oficio bajo mejores condiciones ${ }^{44}$.

\section{4. ¿PERO QUÉ HAY DE MALO EN PROSTITUIRSE?}

En un comunicado de prensa difundido el 18 de mayo de 2006, el sindicato UGT denunciaba que quienes defienden la reglamentación «parecen ignorar que el 95\% de la prostitución no es voluntaria y que el $90 \%$ de la misma la ejercen mujeres inmigrantes, en muchos casos en situación irregular. Además, la voluntariedad de la prostitución... no puede analizarse aislada de las condiciones de vida, culturales, sociales, económicas y de asunción de roles de género que afectan a estas mujeres» ${ }^{45}$. Si nadie discute que se debe perseguir penalmente a quien obliga a otro individuo a alienar su libertad sexual a cambio de un precio, ¿cuál es el error, mal, daño o perjuicio que se comete cuando un legislador decide que las prostitutas voluntarias - aunque sólo constituyan el $5 \%$ - sean consideradas trabajadoras por cuenta ajena o propia y así gocen de la tuición que brinda la legislación laboral ${ }^{46}$ ? Del repaso de la literatura relevante sobre la cuestión, son tres los daños genéricos a los que se apela.

\footnotetext{
${ }^{41}$ «Informe de la Ponencia sobre la prostitución en nuestro país» (aprobada en sesión de la ponencia de 13 de marzo de 2007), Boletín Oficial de las Cortes Generales, 13 de abril de 2007, pp. 2-45, p. 20.

42 VALCÁRCEL comienza su artículo señalando: «A nadie le gusta hablar de la prostitución, ni tampoco que se haga visible en nuestras vidas».

${ }_{43} \mathrm{El}$ «mundo real», indica VALCÁRCEL, de la vulnerabilidad, pobreza y marginación que constituiría el nutriente decisivo de la prostitución.

${ }^{44} \mathrm{Y}$ en esto, la verdad es que las abolicionistas se encuentran por encima de sus diferencias ideológicas o sensibilidades políticas. Así, Ana Botella, exconcejala del Área de Gobierno de Empleo y Servicios a la Ciudadanía del Ayuntamiento de Madrid, afirma también que «... en una abrumadora mayoría de los casos, las personas que ejercen la prostitución no lo hacen voluntariamente», y que «Lejos de poder equipararse a una profesión libremente elegida, la prostitución va unida a la trata de mujeres y menores y a la explotación sexual», en Actas del Congreso Internacional Derechos bumanos y prostitución (Madrid, 22 y 23 de noviembre de 2006), editadas por el Ârea de Gobierno de Empleo y Servicios a la Ciudadanía y la Dirección de Igualdad de Oportunidades del Ayuntamiento de Madrid, 2007, p. 9.

${ }^{45}$ El comunicado es emitido por la Comisión Ejecutiva Confederal. Está disponible en http://www.ugt.es/comunicados/2006/mayo/mayo2006.htm. El Informe de la Comisión Mixta ha hecho suyo este diagnóstico y muchas de las tesis sostenidas por este sindicato con respecto a la laboralización de la prostitución (véase las pp. 21 y ss.).

${ }^{46}$ La cifra del $5 \%$ de prostitución voluntaria frente al $95 \%$ de prostitución forzada se vierte en el comunicado de UGT, así como en otros textos y manifiestos de las asociaciones contrarias al reglamentarismo, sin aportarse el estudio o fuente que avale el dato. Dando por buena esa cifra, hablamos de un colectivo de 20.000 mujeres a quienes el Derecho laboral podría amparar.
} 
En primer lugar se alega que cuando el Estado regula la actividad de las prostitutas como una actividad laboral protegida, se da sobre la misma un pernicioso marchamo de «normalidad». En segundo término se alude a los contraproducentes efectos que tendría la laboralización, que, lejos de atajar los males ínsitos o derivados de la prostitución, contribuiría a aumentarlos. En último término, la laboralización se revelaría imposible en la medida en que conlleva el compromiso con un conjunto de medidas (permisos y obligaciones) con los que, en debida reflexión, no podemos transigir. Todos estos males son, de manera directa o tangencial, destacados en el Informe y por VALCÁRCEL en su artículo. Los analizaré en ese orden.

Los abolicionistas acostumbran a denunciar el pernicioso efecto «pedagógico» que tendría sobre los ciudadanos una intervención legislativa regularizadora de la prostitución. «La ley —aduce VALCÁRCEL— educa a la ciudadanía». Desde esta perspectiva, por tanto, la laboralización estaría mandando a los individuos una señal equivocada: la prostitución es una actividad aceptable ${ }^{47}$. Ese mensaje, remacha VALCÁRCEL, es incompatible con los ideales de ciudadanía e igualdad ${ }^{48}$.

Esta primera consideración tiene mucho calado pues afecta, en definitiva, al modelo de Estado que estimamos mejor. El que parece favorecer VALCÁRCEL es un Estado perfeccionista, un Estado que pretende imbuir virtud a los ciudadanos tratando de que desarrollen planes de vida que (desde algún punto de vista) se consideran valiosos. Un Estado así es el que castiga el adulterio, la interrupción del embarazo, la pornografía, y otras tantas conductas «indeseables», en decir, un Estado que no se conforma, como sí hace el Estado liberal, con relegar los ideales al ámbito de la vida privada de los individuos ${ }^{49}$. Tal vez, como señala VALCÁRCEL, enfrentados con la decisión de si reglamentar o no la prostitución, el abolicionismo como respuesta del Estado perfeccionista es más compatible con los valores de la ciudadanía y la igualdad ${ }^{50}$. El precio se paga, sin embargo, con la moneda de la libertad personal, pues, insisto, existen mujeres y hombres que ven en la compraventa de servicios sexuales una forma de vida aceptable, de la misma forma (sorprendente para mí y para tantos otros) que hay quienes están dispuestos a asear ancianos en residencias u hospitales; o limpiar los baños de una facultad con miles de estudiantes; o vigilar el buen funcionamiento del sistema de alcantarillado de las ciudades, o ser carne de cañón por la defensa de sus compatriotas.

Y es que, en última instancia, está por ver todavía que el acuerdo de dos adultos para practicar sexo a cambio de una remuneración sea una actividad intrínsecamente

${ }^{47}$ Véase la p. 21 del Informe. En esa misma línea se pronunciaba ya Luis JiMÉNEZ DE AsÚA, cuando, describiendo al modelo reglamentarista, afirmaba: «Desde el plano moral, todavía es más lamentable este sistema, ya que conduce indefectiblemente a la trata de blancas, y a pervertir el sentido ético de los jóvenes, haciéndoles pensar que lo que el Estado organiza y reconoce debe ser una necesidad pública»; Libertad de amar..., p. 27.

${ }^{48}$ No es ocioso constatar que para otras pensadoras, sin embargo, es la actual indefensión jurídica que sufren las prostitutas en los Estados en los que impera el abolicionismo o prohibicionismo lo que atenta a la igualdad de esas mujeres y a su capacidad de autogobierno; véase NusSBAUM, 1999: 286-287.

${ }^{49}$ Es un Estado que, al decir del filósofo José Antonio MARINA, puede tener un «gran proyecto ético», en este caso el de la igualdad de las mujeres, que justificaría no dar pábulo a la prostitución mediante su laboralización; véase 2006, p. 58. Muchas mujeres, sin embargo, y como él mismo cita en referencia al colectivo de prostitutas Hetaira, consideran que su igualdad es vulnerada cuando no se les reconoce sus derechos como «trabajadoras del sexo».

${ }^{50}$ En un sentido parecido se manifiesta MARINA, 2006: «... la prostitución, como fenómeno social, es un gran obstáculo para la implantación de los derechos de la mujer», véase p. 51. 
inmoral, como VALCÁRCEL, y otros muchos, presuponen. Hay individuos que, por razones variadas (pensemos en discapacidades objetivas como las razones más evidentes, aunque no las únicas), no pueden realistamente tener vida sexual alguna ${ }^{51}$. ¿Es entonces la masturbación una opción preferible frente al pago de servicios sexuales? ¿Qué resulta más impersonal, frío o empobrecido? — como nos pregunta ERICSSON ${ }^{52}$ - . Si la censura moral a la prostitución tiene su anclaje en la idea de que se trata de una actividad, la del sexo, que debiera ser realizada altruistamente, lo mismo cabría decir de otras tantas necesidades humanas para cuya satisfacción no disponemos de un generoso benefactor sino de un mercado ${ }^{53}$. Tampoco la sexualidad, como actividad que otorga uno de sus sentidos básicos a la condición humana, pierde nobleza por el hecho de que se regule o laboralice la prostitución. Como gráficamente ha señalado Nussbaum la gente se sigue enamorando en Holanda, como también les pasaba en la antigua Grecia ${ }^{54}$; por cierto, también las prostitutas, que, como cualquier otro trabajador o trabajadora, saben discernir entre los usos mercantiles y no mercantiles de su fuerza de trabajo, «... de igual manera que la empleada de hogar puede cocinar para su propia familia y limpiar su propia casa» ${ }^{55}$. En definitiva, y como ha indicado ANDERSON, habida cuenta de que en nuestras sociedades plurales hay un profundo desacuerdo sobre el valor moral del sexo desinteresado, «... un argumento a favor de la conclusión de que la sociedad debe adoptar una postura de condena o prohibición... debe ir más allá de la apelación de uno de esos ideales controvertidos frente a otros» ${ }^{56}$.

Amelia VALCÁRCEL nos propone, aunque de manera sutil, una suerte de test para evaluar la pertinencia de regular la prostitución que supone algo así como calibrar hasta qué punto juzgamos deseable la prostitución como plan de vida para nosotros mis$\operatorname{mos}^{57}$. En un Estado liberal, como decía al iniciar este artículo, hay una demarcación posible entre el pecado y el delito. Sólo aquellos comportamientos que atentan gravemente contra los intereses básicos de la ciudadanía (conductas que normalmente ciframos como atentatorias a los derechos humanos) resultan castigadas, aunque pueda seguirse sosteniendo - desde el punto de vista ético- que abortar es siempre una decisión grave, no trivial (e incluso equivocada moralmente), o que nunca resulta recomendable engañar a nuestra pareja, y que ambos comportamientos no los consideramos deseables ni para nosotros mismos ni para nadie, y que, puestos a elegir, preferiríamos que nuestra hija fuera médico antes que celadora, limpiadora, actriz porno o prostituta. Esos

${ }^{51}$ Se debe insistir en que las razones para comprar servicios sexuales a una prostituta no son únicamente la imposibilidad de satisfacer los deseos sexuales de manera espontánea y desinteresada. En una reciente encuesta llevada a cabo en Dinamarca se ha constatado que la mayoría de los clientes son hombres casados o que viven en pareja. Sólo el $8 \%$ de los encuestados respondió que acudir a los servicios de las prostitutas era la única manera de obtener sexo; véase LAUTRUP, C., 2006: pp. 74, 81. Lo mismo cabe decir del cliente británico, de acuerdo con los datos que proporciona KinNELL: el 65\% de ellos están casados o emparejados.

${ }^{52}$ ERICSSON, L. O., 1980: p. 340. Con ello ni Ericsson, ni yo mismo, estamos queriendo excusar o justificar la prostitución sólo en los supuestos en los que el individuo esté objetivamente impedido para la satisfacer desinteresadamente su necesidad sexual. Alguien que no esté en ese caso puede preferir, también por variadas razones, pagar los servicios de una prostituta.

53 Ibid., pp. 341-342 y Hilary KINNELL.

54 1999: 290.

55 Ibid., p. 291.

56 ARnESON, 1992: 153. En la misma línea, Nussbaum, 1999: 286.

57 «... muchas personas que no la contemplan en el horizonte de lo deseable para ellas mismas — dice VALCÁRCEL — no tienen reparos en manifestar que la prostitución pueda ser un modo de vida para "algunas" mujeres». 
juicios sobre el aborto, el adulterio, la prostitución o la pornografía pueden ser compartidos, pero no así, en cambio, el ulterior y decisivo paso consistente en afirmar que sólo por esa razón debe el Estado castigar. Esto último era precisamente lo que distinguía la posición de Herbert HART de la de Lord DEVLIN en el célebre debate que ambos mantuvieron a propósito de la despenalización de la homosexualidad en el Reino Unido.

Sí, sí, ya se que ni VALCÁRCEL ni la Comisión Mixta quieren encarcelar a la prostituta y/o al cliente. Pero entonces, ¿qué quieren con respecto a las mujeres que voluntariamente se prostituyen? Si es que, como parece, se asume la idea de que también las prostitutas voluntarias son víctimas, la Comisión Mixta propugna la creación de un Sistema de Atención Social para ellas ${ }^{58}$. El contenido de tal «sistema» permanece ignoto para el lector del Informe una vez llega a su final, aunque el uso de mayúsculas augura que deberá ser algo muy trascendental, una institución que justificará seguramente una jugosa dotación presupuestaria y de personal a cargo del erario público.

En otras épocas, el perfeccionismo moral que se esconde tras esta medida se cifró en la propuesta de fundar un asilo donde las jóvenes encontraran «instrucción, trabajo y moralidad», pues la causa de la prostitución, según su promotora, la protofeminista María Teresa VERDEJo DuRÁn, era el abandono de la educación moral y el «instinto del lujo» ${ }^{59}$. Más tarde, en plena vorágine abolicionista, se fundó el Patronato de Protección de la Mujer que funcionó entre 1931 y 1935 con la pretensión, igualmente, de «reeducar» a las mujeres dedicadas a la prostitución. Para los comunistas, en cambio, la prostitución se vinculaba íntimamente con el capitalismo, con lo que su erradicación habría de esperar a la implantación de la sociedad comunista como había ocurrido en la URSS donde la prostitución se había prohibido. Mientras tanto, la organización anarquista «Mujeres libres» (el equivalente a la sección femenina de la CNT-FAI) instaba a la creación de unos asilos («Liberatorios de Prostitución») donde la mujer podía recibir ayuda y formación para «liberarse». Los liberatorios serían hogares colectivos en los cuales poner en práctica una «... reeducación de la mercenaria, su examen psicológico y psicotécnico, a fin de investigar las motivaciones espirituales que le indujeron a su profesión y las causas de su fracaso social $\gg^{60}$. Los anarquistas consideraban que la prostituta representa el estadio final de un proceso de desadaptación social, amorosa y biológica, todo lo cual no era sin embargo incompatible, a ojos del anarquismo, con propugnar el amor libre y la libertad sexual de las mujeres tal y como hacía la Ministra de Sanidad Federica Montseny ${ }^{61}$.

Este empeño perfeccionista que concibe a las prostitutas como descarriadas o menores de edad permaneció invariable bajo el franquismo (el Patronato se convirtió en Junta Nacional cuya presidencia de honor ostentó la mujer del dictador), aunque a la justificación basada en el abandono del vicio se sumó la educación de acuerdo con la religión católica ${ }^{62}$. Entonces, el apóstol del abolicionismo (JIMÉNEZ AsENJO) se vana-

\footnotetext{
${ }^{58}$ Véanse las pp. 21, 23 del Informe.

59 Véase GUEREÑA, 2003: 341-342. VERDEJO fundó la revista La Mujer (1852) una de las primeras publicaciones «feministas» en nuestro país.

${ }^{60}$ La cita la tomo de GUEREÑA, 2003: 408.

${ }^{61}$ Ibid., p. 409.

${ }^{62}$ Id., p. 423. Un manifiesto elocuente de ese fermento de moral católica que nutre el abolicionismo de la época franquista es el libro de JIMÉNEZ ASENJO (véase supra nota 33), en el que se leen consideraciones como
} 
gloriaba de la política de regeneración que había puesto en práctica el Patronato. Aunque la cita es larga, no me resisto a transcribir íntegramente el contenido de su descripción: «Recientemente, se ha establecido en "Villa Teresita", en Granada, conforme a las más recientes recomendaciones de la política internacional abolicionista... un régimen de acogimiento a puerta abierta, donde van llegando jóvenes que cansadas de la mala vida buscan allí su regeneración. Esta Institución, juntamente con la de "Villa Teresita", de Pamplona y de Valencia, y el resto de las instituciones acogedoras que ya poseía el Patronato para la protección y readaptación de la joven caída, constituyen los hitos de una política regeneradora del vicio y de la mujer explotada, que en España es hoy una realidad y augurio de un futuro lleno de esperanzas redentoras de la explotación humana...» ${ }^{63}$.

Con similar tono voluntarista y moralista, aunque con una jerga menos inflada que la que fue característica de la II República y del franquismo, la Comisión Mixta propone que se ofrezcan Planes (en mayúsculas también, por supuesto) que posibiliten alternativas de vida a las prostitutas (previa asistencia psicológica que les permita «recuperar su dignidad y autoestima») ${ }^{64}$ impulsando itinerarios de inserción laboral que posibiliten su abandono de la prostitución, y que se realicen campañas de sensibilización para cambiar «... la percepción social del uso de las mujeres como mercancía sexual y obtener una repulsa social generalizada hacia el comercio sexual como una vulneración de los derechos fundamentales de las mujeres en situación de prostitución...», todo ello con el objetivo de reducir la demanda. En el ínterin se insta a que se facilite a las prostitutas una «renta de inserción activa» ${ }^{65}$, y, alcanzando así el summum de la contradicción pragmática, se declara en el Informe la necesidad de «... conocer en profundidad la situación de la prostitución en nuestro país mediante investigaciones cuantitativas y cualitativas, teniendo en cuenta que es un fenómeno dinámico» ${ }^{66}$.

las siguientes: «... reconocida la necesidad biológica de la efusión amorosa bisexual, ésta sólo puede verificarse lícitamente en la unión matrimonial. El hombre y la mujer únicamente pueden conocerse, sin pecado, después del matrimonio y sólo dentro del matrimonio» (pp. 26-27). En referencia a las causas de la prostitución, JIMÉNEZ ASENJO considera decisivas para la «caída» el hecho de la orfandad o la falta de «formación hogareña» (pp. 150-151). Sobre el amor libre, considera que no hay tal porque, «... equiparado al amor sincero y auténtico amor, existió siempre que un hombre y una mujer se encontraron en la vida y juntos y enamorados llegaron hasta la muerte. Es tan viejo como la humanidad y morirá con ella. Todo matrimonio le presupone y a él van dirigidas todas sus prevenciones y a ello alude el simbolismo de sus galas y ritos. El sacramento es la santificación del amor puro, el amor libre, que conduce a la pareja hasta el altar» (p. 181). Los ejemplos podrían multiplicarse.

63 1963: p. 220. Para esa tarea, insiste JiMÉNEZ AsENJO, contamos con «El ejemplo luminoso del Evangelio, en que Cristo transforma y redime a la Samaritana y la pecadora pública impenitente María Magdalena... No es preciso ser superhombres para entregarse, con fe, a la tarea... Basta con ser hombres o mujeres enamorados de un ideal de redención humana, para aceptar la empresa con fervor apostólico, a imitación del Gran Maestro» (ibid., p. 294).

${ }^{64}$ Véase la p. 26 del Informe.

${ }^{65}$ Actualmente asciende a 432 euros al mes con un máximo de 11 meses. El ministro de Trabajo, Jesús Caldera, proponía ya en febrero de 2006 esta medida (véase El País, de 11 de febrero de 2006). Algunas prostitutas de Madrid acogían con escepticismo la propuesta, tal y como se narraba en el reportaje «La calle desde la calle» firmado por Ana Alfageme, en la edición de El País, de 11 de febrero de 2006, p. 29. La mayoría de las entrevistadas declaraban ganar por encima de 700 euros al mes. «Mejor nos volvemos a Rumanía», concluía una de las prostitutas preguntada sobre la iniciativa del ministro Caldera.

${ }_{66}^{6} \mathrm{Ibid}$., p. 24. Esta declaración sorprende si tenemos en cuenta que el objeto de la Ponencia creada en el seno de la Comisión era «... el estudio de la situación actual de la prostitución en España y la concreción de orientaciones y propuestas transversales que se deban desarrollar en todos los ámbitos». Se trataba, así, de dar 


\section{EL «REGLAMENTARISMO REFORZADO»}

Vayamos con la segunda de las «razones» del abolicionismo: lo contraproducente del reglamentarismo.

En Holanda y en Alemania la prostitución está reglamentada como una actividad lícita. Ambos países abanderan la opción que algunos autores denominan «reglamentarismo reforzado» $\mathrm{o}$ «neo-reglamentismo» ${ }^{67}$, un modelo que habría sido amparado nada más y nada menos que por el Tribunal de Justicia de la Unión Europea en una sentencia ya célebre del año 2001 ${ }^{68}$. En 1993 las Comunidades Europeas, por un lado, y Polonia y Checoslovaquia por otro, suscribieron un Acuerdo de Asociación en cuyos artículos 44, 45, 58 y 59 se dispone que desde el momento de la entrada en vigor de dicho Acuerdo, los Estados miembros permitirán que los nacionales polacos y checoslovacos establezcan sociedades y ejerzan actividades económicas por cuenta propia en su territorio. ¿Comprendían dichas actividades también el ejercicio de la prostitución tal y como alegaban las señoras Szepietowska, Padevetova, Zacalova, Hrubcinova y Überlackerova, prostitutas de escaparate que trabajaban en Ámsterdam, frente a las autoridades holandesas? La respuesta del Tribunal fue afirmativa ${ }^{69}$. No cabe apelar, abundaba el Tribunal, a una razón de «orden público» para mantener una excepción a la regla general de no discriminación entre nacionales de los Estados Miembros y nacionales polacos o checoslovacos ${ }^{70}$.

En Holanda la prostitución era una actividad legalmente amparada desde la reforma del Código Penal producida el 1 de octubre de 2000 mediante la cual se abolió la prohibición de la explotación del trabajo sexual voluntario ${ }^{71}$. Holanda se convirtió entonces en el país pionero en la legalización de la prostitución voluntaria, pues, a la despenalización sumó la consideración de los prostíbulos como un negocio sometido al régimen general de licencias municipales, y del trabajo de las prostitutas como una actividad laboral que otorga a aquéllas derechos tales como pensión de invalidez, acceso a las

cumplimiento al mandato del Pleno del Congreso de los Diputados que mediante moción aprobada el 14 de febrero de 2006 instaba a «... iniciar en el seno de la Comisión Mixta de los Derechos de la Mujer, un proceso de estudio, debate y comparecencias, con el objetivo de elevar un dictamen informativo, dentro del presente período de sesiones, que permita concluir con un diagnóstico sobre la situación actual de la prostitución en nuestro país, concretando orientaciones y propuestas transversales que se deban desarrollar en todos los ámbitos».

${ }^{67}$ Véase FERNÁNDEZ et al., 2007: 9-12 y HeIm y MONFORT, 2005: 773. Junto a Holanda y Alemania, también en Australia (Brothel Health Regulation Act, de 1990) y Nueva Zelanda (Prostitution Reform Act, de 2001), se ha optado por esta vía. Un resumen de esta última en REY et al., 2004: 34-36.

${ }^{68}$ La sentencia es de 20 de noviembre de 2001, asunto C-268/99.

${ }^{69}$ Considerando 49.

${ }^{70}$ Afirma literalmente el Tribunal en el Considerando 60: «Aunque el Derecho comunitario no impone a los Estados miembros una escala uniforme de valores para la apreciación de aquellos comportamientos que puedan considerarse contrarios al orden público, no cabe considerar que un comportamiento es lo suficientemente grave como para justificar la imposición de restricciones a la entrada o a la estancia en el territorio de un Estado miembro de un nacional de otro Estado miembro si, cuando el mismo comportamiento proviene de sus propios nacionales, el primer Estado no adopta medidas represivas u otro tipo de medidas reales y efectivas destinadas a combatir este comportamiento». De manera sorprendente, el gobierno holandés había alegado que no cabe considerar la prostitución como una actividad económica por cuenta propia puesto que nunca es posible determinar fehacientemente que el ejercicio de la actividad no se practica con subordinación al proxeneta (considerando 54). Este razonamiento, por lo que parece, no se aplica cuando de nacionales holandesas hablamos.

${ }^{71}$ Sobre los antecedentes históricos y avatares de esa reforma, véase HeIm y MONFORT, 2005: 789. 
pensiones, salario mínimo, derecho a sindicarse, y a negarse a la realización de un determinado servicio, etc. ${ }^{72}$. En Alemania se ha ido un paso más allá pues la prostitución puede constituir, desde la reforma del año 2002, una relación laboral por cuenta ajena. La reforma se ha llevado a cabo mediante una exigua ley con la que se despenaliza la gestión de los burdeles que cumplan ciertas exigencias; se incorpora a las prostitutas al régimen general de la seguridad social al considerarse su dedicación un trabajo, y no una actividad inmoral ni contraria a las buenas costumbres o al orden público, con lo que civilmente el contrato entre la prostituta y el cliente es un contrato ejecutable aunque sólo unilateralmente (por parte de la prostituta) ${ }^{73}$.

$¿$ ¿Han sido contraproducentes las experiencias alemana u holandesa? ¿Se ha probado más eficaz el «experimento» sueco? Abundan los estudios y valoraciones sobre todas ellas, aunque, en relación con esta última, resulta reveladora la opinión de Anders OljELund, Embajador para la Cooperación Internacional contra el tráfico de seres humanos del Ministerio de Asuntos Exteriores de Suecia: « ¿Ha tenido la ley sueca contra la compra de servicios sexuales algún efecto preventivo? —se pregunta- ¿ ¿La criminalización de los compradores de servicios sexuales ha reducido la prostitución en Suecia, o sólo la ha desterrado de las calles. Es difícil saberlo. Pero al menos tenemos cierta prueba de que ha desalentado a los traficantes a utilizar Suecia como un mercado con fines sexuales. Ya no es tan rentable como lo podría ser. Esto es lo que nos dice la policía, pero es difícil proporcionar una prueba en números» ${ }^{74}$.

Otros estudios, en cambio, son más rotundos en la afirmación de que el efecto de la ley sueca sobre la prostitución callejera ha sido fulminante, lo cual, sin embargo, «... no significa que la prostitución en Suecia haya sido abolida, sino más bien que el escenario de la calle se ha trasladado al interior de algún hotel, restaurante, club nocturno o alguna casa particular» ${ }^{75}$.

En Holanda, distintos informes avalan que la legalización ha hecho menos atractivo el negocio para el crimen organizado, aunque también se reconoce que queda un largo trecho por recorrer en la mejora de las condiciones bajo las cuales desarrollan su actividad las prostitutas (la prestación por desempleo sigue sin ser efectivamente garantizada). Ello es debido a la persistencia del estigma social que, a pesar de todo, sigue llevando aparejada la prostitución en Holanda ${ }^{76}$.

72 Así se introdujo en la ley de 28 de octubre de 1999. Con el límite de la prohibición absoluta, cada gobierno local es responsable de su propia política en materia de prostitución (en Rotterdam, por ejemplo, la prostitución callejera y de escaparate está prohibida; véase HEIM y MONFORT, 2005: 803).

${ }_{73}$ La referencia a la ley es: Gesetz zur Regelung der Rechtsverbältnisse der Prostituierten (Prostitutionsgesetz -ProstG-) of 20 Dec. 2001, Bundesgesetzblatt (BGBl.), I, 2001, p. 3983. Un buen comentario sobre la misma es el de LASKOWSKI, S. R., 2002. Con esta medida de la unilateralidad a favor de la prostituta de la ejecución del contrato, se está queriendo evitar, como en otros ámbitos, la obligación de prestar un servicio, en este caso, personalísimo. También se evita que, como ocurre en otras prestaciones personales, el incumplidor pueda verse obligado a indemnizar con un equivalente dinerario. En definitiva, la prostituta será únicamente la que podrá reclamar el dinero por el servicio prestado, pero no así el cliente solicitar un servicio acordado o una indemnización equivalente por la no prestación del mismo.

${ }^{74}$ 2006: 63 (cursivas mías).

75 Heim y Monfort, 2005: 785. Las autoras se refieren a un estudio llevado a cabo por el Maxim Institute en 2003. Hasta abril de 2003 ningún cliente había sido condenado a pena de prisión (ibid., p. 786).

${ }^{76}$ HeIm y MONFORT, 2005, pp. 805-806. REY et al., destacan sin embargo que la prostitución ilegal de mujeres de los países del Este no ha disminuido; véase Prostitución y Derecho, op. cit., p. 33. 
Por último, se ha de tener en cuenta que, de acuerdo con una investigación llevada a cabo por el canal 4 británico, cuando la demanda de los servicios de las prostitutas se reduce por la presión policial sobre los clientes, el $65 \%$ de las mujeres declaraban trabajar más horas, y el $40 \%$ «muchas más horas», a pesar de lo cual el $66 \%$ de las mismas afirmaba ganar menos. Además, sus propias medidas de seguridad se relajaban, y, así, el $53 \%$ de ellas empleaba menos tiempo en examinar al cliente antes de acceder a su coche. El $24 \%$ admitían el haber consentido a realizar «servicios» a los que en otro caso se habrían negado (principalmente, no utilizar preservativo) ${ }^{77}$. El estudio viene así a confirmar una intuición dictada por el sentido común: la criminalización tiene el efecto cierto de añadir riesgo y penosidad al ejercicio de la prostitución. Está por demostrar con mayor rigor, sin embargo, que con la laboralización aumente la prostitución no consentida, único efecto contraproducente que debería hacer repensar las opciones tomadas en Alemania y Holanda, pues el otro efecto (el que no se destierre con ello una forma poco edificante de ganarse el pan) no puede, en un Estado liberal, ser utilizado como razón para el sacrificio de la libertad individual o para la discriminación, frente a otros trabajadores, de las mujeres que se prostituyen voluntariamente ${ }^{78}$.

\section{6. ¿O TODO O NADA?}

El diario La Voz de Galicia se hacía eco, en su edición de 3 de febrero de 2005, de que una joven alemana de 25 años, informática en paro, había recibido de los servicios sociales una oferta para trabajar en un burdel ${ }^{79}$. La cuestión se hace más chocante, si cabe, cuando tenemos en cuenta que la legislación alemana imponía severos recortes en sus derechos de prestación a aquellos parados que rechazaran las ofertas de empleo que les fueran presentadas ${ }^{80}$.

Este hecho sorprendente epitomiza muy bien la tercera de las razones apuntadas contra la laboralización de la prostitución: incluso si admitiéramos, por razones pragmáticas o consecuencialistas, la pertinencia de dar mayor seguridad y mejores condiciones laborales a las prostitutas, no se puede regular la prostitución como un trabajo por las consecuencias indigeribles que dicho paso acarrea. Que tales consecuencias no son fácilmente admisibles es un hecho que deriva de que, en última instancia, no consideramos que la prostitución pueda ser concebida cabalmente como un trabajo más ${ }^{81}$. Es más, si efectivamente quedamos persuadidos de que las prostitutas, como se acostumbra a decir, cumplen una «función social», ¿por qué no incluir sus servicios entre las prestaciones del Estado de bienestar? —se pregunta en esa línea José Antonio MARINA ${ }^{82}$.

${ }^{77}$ La encuesta, sobre una muestra de 118 prostitutas, es citado por KINNELL (véase http://www.nswp. org/pdf/KINNELL-FEMINISTS.PDF).

${ }^{78}$ En esa línea también se ha manifestado Nussbaum, 1999: 295.

79 La noticia explica que la demandante de empleo había incluido una previa experiencia como «camarera» en el momento de recabar la ayuda de los servicios sociales, y tal dato había animado a un empresario alemán a proponerle trabajar en su establecimiento ofreciendo sus servicios sexuales.

${ }_{80}$ Ciertamente, en su momento, el legislador alemán había considerado la posibilidad de excluir de dicha regla a las propuestas de «empleos inmorales», pero finalmente no lo hizo. La razón esgrimida fue la dificultad de distinguir entre los muy distintos tipos de establecimientos donde se comercia con servicios sexuales.

${ }^{81}$ El argumento fue expuesto con brillantez hace ya tiempo por Margaret RADIN; véase 1987, pp. 1922, 1924-1925.

${ }^{82}$ Así, Marina, 2006: p. 50. 
Una relación tiene carácter laboral cuando la actividad que se realiza reúne las notas de la voluntariedad (en otro caso hablamos de «trabajos forzados», cumplimiento de castigos, o esclavitud); remuneración (no «trabaja» quien altruistamente hace cosas para los demás); ajenidad (es el otro quien se hace con los frutos de nuestro trabajo, asumiendo a cambio el riesgo empresarial) y dependencia (quien trabaja, se halla, durante el tiempo de trabajo, bajo el poder de dirección y organización de ese otro, el empleador). Esta última se presenta como la característica de la relación laboral que suscita más recelos a la hora de apostar por la consideración de que la prostitución debe ser un trabajo: «Parece difícil cohonestar un espacio para la libertad sexual cuando ésta debe estar dirigida y organizada por la dirección de una pretendida empresa dedicada al comercio sexual, porque esta libertad está por encima de toda organización empresarial» ${ }^{83}$. Con mayor crudeza se pronuncia la juez María Antonia Lozano Álvarez: «¿Señalaremos cuántos coitos pueden hacer — las prostitutas — en una jornada de ocho horas, si han de dejarse atar o insultar? ¿Les regularemos el período de descanso cuando menstrúen?» ${ }^{84}$.

Frente a ello cabe señalar que toda relación laboral implica, por definición, cesión en la libertad personal. Los «viajes de trabajo» que millones de empleados tienen que realizar son restricciones a la libertad de movimientos. Obviamente no parece lo mismo la obligación de desplazarse de un punto a otro que la de prestar un servicio sexual, aunque en ambos casos están comprometidos derechos fundamentales. Pero pensemos en la producción de películas pornográficas: los actores porno aceptan representar un papel que les exige un buen número de compromisos con el ejercicio de su sexualidad de acuerdo con las pautas que impone un director. Pues bien, de la misma manera que ese actor o actriz debe poder disponer de todos los detalles sobre el trabajo que se espera que haga en la película (en especial sobre quiénes serán sus partenaires), la prostituta que trabaja por cuenta ajena ha de poder rechazar la prestación de un servicio a un determinado cliente. Las legislaciones que se han inclinado por la laboralización así lo contemplan ${ }^{85}$.

La idea es por tanto la de tamizar o adecuar ese haz de rasgos, prestaciones, obligaciones y derechos que acompaña a la relación laboral típica o genérica. En Holanda, por ejemplo, las prostitutas tienen derecho a todas las prestaciones de la seguridad social excepción hecha del desempleo, probablemente porque se considera que la probabilidad de fraude es muy alta ${ }^{86}$ (lo mismo cabría decir de la categorización de las enfermedades de transmisión sexual como enfermedades profesionales de las prostitutas) ${ }^{87}$.

${ }^{83}$ REY et al., 2004: 179-180. En una línea similar se pronuncia el juez de lo Social de Granollers en sentencia de 22 de noviembre de 2002 ( $A S$ 1276): «... nadie puede organizar ni dirigir la actividad sexual de ninguna mujer, porque atenta contra los derechos fundamentales y la dignidad humana» el comercio sexual no puede ser objeto lícito de contrato de trabajo ya que la capacidad de decidir y la libertad sexual están por encima de la dirección y la organización empresarial» (citado por REY et al., 2004: 196).

${ }^{84}$ En Actas del Congreso Internacional Derechos Humanos y Prostitución (Madrid, 22 y 23 de noviembre de 2006), op. cit., pp. 148-156, p. 155.

${ }_{85}$ Véase FERNÁNDEZ, R. et al., 2007: pp. 22-23. No resulta obvio, por tanto, que como indican ReY et al., «... ante estas prestaciones de naturaleza sexual la nota de dependencia no sólo sufre una relajación, matización o adaptación sino que, a nuestro juicio, llega a desaparecer perdiendo su significado de subordinación» (REY et al., 2004: 181). Me remito de nuevo al contraejemplo de las películas o espectáculos pornográficos.

${ }^{86}$ Esto mismo se aduce cuando de extender la prestación por desempleo a trabajadores autónomos y empleadas de hogar se habla.

${ }^{87}$ ¿Cómo tener claro que el contagio del SIDA se produjo mientras «se trabajaba»? 
De la misma forma, tampoco parece recomendable extender a la prostitución, considerada como actividad laboral, la posibilidad de trabajar a los mayores de dieciséis años; o incluir entre las modalidades de contrato en el ámbito de la prostitución, el contrato en prácticas y para la formación; o extender la jornada laboral general cuando estamos ante una actividad que ciertamente exige menos horas y más pausas; o equiparar la edad de jubilación; o permitir el llamado «despido objetivo» por ineptitud (la falta de habilidades o carencia de facultades) o por falta de adecuación del trabajador a las «modificaciones técnicas» de su puesto de trabajo, si con ello el empleador puede sortear su obligación de respetar que la prostituta no acepte la relación sexual con determinados clientes o ciertos servicios. Parece, por último, que quien emplea a prostitutas debe asumir la prevención de riesgos típicos en esta actividad, y, así, estar obligado, como establecen los artículos 12.2. y 12.3 del Decreto Catalán 217/2002, a poner preservativos a disposición de sus empleadas y empleados y a exigirles su uso, e igualmente a que dispongan de revisiones médicas periódicas ${ }^{88}$.

Alguno pensaría que, una vez hechos tantos retoques al cuadro, del original (la ecuación prostitución=trabajo) no queda nada. En el fondo, que el intercambio de sexo por dinero pueda finalmente ser llamado trabajo como todos los demás, es lo de menos. Se puede aceptar que la prostitución no encaja ni debe encajar en el lecho de Procusto de las actividades laborales «normales», pero lo importante es que, hechas las tamizaciones necesarias, las prostitutas tengan mejores condiciones en el ejercicio de su actividad y más derechos y garantías. No serían, por cierto, las únicas «trabajadoras especiales» o «pseudotrabajadoras». Se sumarían a quienes, también por sus muchas especificidades, engrosan la panoplia de relaciones laborales especiales que recoge el artículo 3 del Estatuto de los Trabajadores: mineros, profesionales taurinos, trabajadores del mar, deportistas, artistas, etc. ¿Por qué no?

\section{CONCLUSIONES}

A lo largo de las anteriores páginas he tratado de argumentar a favor de la llamada «regulación» de la prostitución, es decir, de que la voluntaria prestación de servicios sexuales a cambio de un precio pueda considerarse como una relación laboral.

Para ello he analizado las razones que se aducen en contra de dicha opción «reglamentarista», un elenco de argumentos que se presentan agrupados bajo el estandarte del llamado «abolicionismo». He insistido, en primer lugar, y frente a lo que algunas abolicionistas esgrimen, que la actividad para la que se reclama «licitud», licitud que deriva de la categorización de la prostitución como «trabajo», es la prostitución voluntaria y que es sobre ésta sobre la que se centra el debate genuino acerca de qué hacer desde el punto de vista normativo e institucional con un fenómeno social inquietante y desasosegante desde tiempos remotos. Frente a lo que algunas abolicionistas esgrimen,

${ }^{88}$ Este elenco de «especificidades» o adecuaciones que habría de sufrir la prostitución como actividad laboral está tomado del exhaustivo e iluminador análisis de FERNÁNDEZ, R. et al., 2007: pp. 24-26, 29, 32-33, 4243, 48. Sin duda la cuestión más sensible, a día de hoy, es la posibilidad de que, considerada la prostitución como una relación laboral, se pueda conceder un permiso de trabajo para el ejercicio de la prostitución a mujeres extranjeras (ibid., p. 31). 
existe la prostitución voluntaria; la prostitución no equivale «por definición» a esclavitud. En todo caso, puestos a considerar la prostitución como algo esencialmente denigrante o indigno para los seres humanos (equiparable a la compraventa de órganos, por ejemplo) la actitud coherente por parte del Estado no es la «desregulación» (que implica que la prostitución no es delito pero no se ampara jurídicamente a quien la ejerce), sino la prohibición bajo la amenaza de la sanción penal. Esa es la respuesta, con todo, de un Estado perfeccionista que trata de que los ciudadanos desarrollen sólo aquellos planes de vida que se estiman deseables o virtuosos, lo cual conlleva una restricción insoportable del ideal de la libertad individual.

Junto a todo lo anterior, los abolicionistas aducen que la laboralización incrementa los males propios o derivados de la prostitución —un argumento de naturaleza empírica- y que, de ser considerada la prostitución como un trabajo, tendríamos que admitir también ciertas consecuencias de dicha equiparación que se nos presentan como indeseables. La respuesta a ambos argumentos se deja sintetizar fácilmente: en cuanto a lo primero, la evidencia no es concluyente (e incluso si lo fuera, está por demostrar que la prostitución voluntaria es una dedicación innoble si tenemos en cuenta otros muchos oficios humanos que, igualmente denigrantes, no pensamos que haya que procurar desterrar); en cuanto a lo segundo, las relaciones laborales son matizables en función de las circunstancias del empleo, es decir, nada impide que excepcionemos algunos de los derechos, obligaciones y garantías institucionales ligados al trabajo por cuenta ajena, si es que, como creo que es digno pretender, queremos que las prostitutas tengan una vida mejor, aunque pensemos en el fondo que hay mejores empleos.

\section{BIBLIOGRAFÍA}

ARneson, R. J., 1992: «Commodification and Commercial Surrogacy», Philosophy and Public Affairs, vol. 1, n. ${ }^{\circ}$ 2, spring, pp. 132-164.

De la Villa SeRna, D., 2004: «Relaciones laborales de hecho, nulidad del contrato de trabajo y actividades laborales de causa u objeto ilícitos o contrarios a las buenas costumbres. Comentario a la doctrina judicial sobre el "alterne"», Revista General del Derecho del Trabajo $y$ de la Seguridad Social-Iustel, n. ${ }^{\circ}$ 6, 2004, pp. 1-12.

EdLund, L., y Korn, E., 2002: «A Theory of Prostitution», The Journal of Political Economy, vol. 110, n. $^{\circ} 1$, pp. 181-214.

ENGELS, F., 1884 (1982): El origen de la familia, la propiedad privada y el Estado, Madrid: Fundamentos.

Ericsson, L. O., 1980: «Charges Against Prostitution: An Attempt at Philosophical Assessment», Ethics, vol. 90, n. ${ }^{\circ} 3$, abril, pp. 335-366.

Fernández, R.; TASCÓN LÓPeZ, R.; Álvarez Cuesta, H., y Quirós Hidalgo, J. G., 2007: «Sobre la posible regularización laboral de la prostitución: reflexiones para un debate», Revista de Trabajo y Seguridad Social, n. ${ }^{\circ} 289$, abril, pp. 3-50.

GueReñA, J.-L., 2003: La prostitución en la España contemporánea, Madrid: Marcial Pons.

HeIM, D., y MONFORT, N., 2005: «Vigilar y castigar: las nuevas propuestas de políticas públicas para la prostitución en Europa. Análisis de los modelos de Suecia y los Países Bajos», Nueva Doctrina Penal, n. ${ }^{\circ}$ 2, pp. 771-812. 
JimÉnEZ AsEnJo, E., 1963: Abolicionismo y prostitución, Madrid: Reus.

JimÉNEZ DE ASÚA, L., 1928: Libertad de amar y derecho a morir, Madrid: Historia Nueva.

KinNell, H.: «Why Should Feminists Should Rethink on Sex Workers' Rights», en http://www. nswp.org/pdf/KINNELL-FEMINISTS.PDF.

Laskowski, S. R., 2002: «The New German Prostitution Act- An Important Step To A More Rational View of Prostitution as an Ordinary Profession in Accordance With European Community Law», The International Journal of Comparative Labour Law and Industrial Relations, vol. 18, n. $^{\circ}$ 4, pp. 479-491.

LAUTRUP, C., 2006: «No es sólo una experiencia cuerpo a cuerpo», en Actas del Congreso Internacional Derechos Humanos y Prostitución (Madrid, 22 y 23 de noviembre de 2006), Área de Gobierno de Empleo y Servicios a la Ciudadanía y la Dirección de Igualdad de Oportunidades del Ayuntamiento de Madrid, pp. 68-87.

Lousada Arochena, J. F., 2005: Prostitución y trabajo: la legislación española, ponencia presentada en el Congreso Internacional sobre Explotación Sexual y Tráfico de Mujeres celebrado en Madrid los días 26, 27 y 28 de octubre de 2005.

MARINA, J. A., 2006: «Lucha por la dignidad», en Actas del Congreso Internacional Derechos Humanos y Prostitución (Madrid, 22 y 23 de noviembre de 2006), Área de Gobierno de Empleo y Servicios a la Ciudadanía y la Dirección de Igualdad de Oportunidades del Ayuntamiento de Madrid, pp. 40-59.

Nussbaum, M. C., 1999: «"Whether from Reason or Prejudice”: Taking Money for Bodily Services», en Sex and Social Justice, New York: Oxford University Press, pp. 276-298.

Oljelund, A., 2006: «La explotación sexual. Una visión sueca», en Actas del Congreso Internacional Derechos Humanos y Prostitución (Madrid, 22 y 23 de noviembre de 2006), Área de Gobierno de Empleo y Servicios a la Ciudadanía y la Dirección de Igualdad de Oportunidades del Ayuntamiento de Madrid, pp. 60-67.

Pateman, C., 1983: «Defending Prostitution: Charges Against Ericsson», Ethics, vol. 93, issue 3, april, pp. 561-565.

QUiNTERO OlivareS, G., 2006: «Las normas penales españolas: cuestiones generales», en Trata de personas y explotación sexual, GARCíA ARÁN, M. (coord.), Granada: Comares, pp. 157195.

Radin, M. J., 1987: «Market-inalienability», Harvard Law Review, vol. 100, n. ${ }^{\circ}$ 8, june, pp. 18491937.

REY, F. et. al., 2004: Prostitución y Derecho, Cizur Menor (Navarra): Aranzadi. 